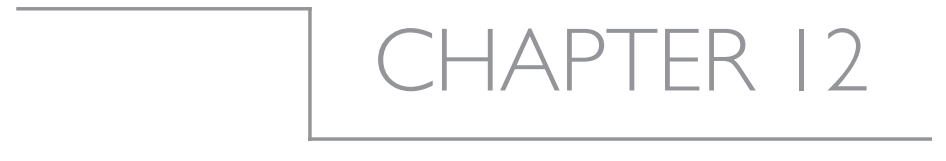

\title{
CONSERVATION AND MANAGEMENT
}

\section{Marienne S. De Villiers and John CoOper}

Human interest in the Prince Edward Islands was initially commercial, centred on the economic worth of resources such as the large populations of breeding seals. Later, the interest was strategic due to the islands' location in the Southern Ocean between South Africa and the Antarctic Continent (Cooper \& Headland 1991; Cooper 2008). This location also made the islands valuable to South Africa as a centre from which to predict weather. Although this is still an important consideration, the islands are increasingly valued for their worth in terms of research and conservation. Islands in the Southern Ocean are prized in this regard because they are few and isolated, have had relatively low levels of human impact, and have unique species assemblages. The subAntarctic region has experienced a relatively rapid increase in temperature compared with the rest of the world. The Prince Edward Islands, with their relatively simple terrestrial ecosystems, represent ideal sites for the study of ecosystem processes and their responses to climate change (Pakhomov \& Chown 2003). The islands also act as a "frontier zone" in terms of monitoring and/or regulating environmental impacts in Antarctica (PEIMPWG 1996). Furthermore, the Prince Edward Islands and their surrounding waters serve as breeding and moulting grounds for up to five million top predators seasonally, providing feeding grounds for seabirds, seals and migrating whales, and support a commercially exploited demersal fish population (Pakhomov \& Chown 2003).

S.L. Chown E P.W. Froneman (eds.) The Prince Edward Islands $\bullet$ Land-Sea Interactions in a Changing Ecosystem, 301-330 
Despite the value of the islands from a conservation and research perspective, they are subject to a number of threats. These include the introduction of alien species, the depletion of and effect of climate change on marine resources, pollution of the marine inshore and terrestrial environments, and disturbance of wildlife and significant sites. These are threats common to all Southern Ocean islands (De Villiers et al. 2006a) and active management is necessary to control or limit them. This chapter first summarises the evolution of the management of the Prince Edward Islands over the period of nearly sixty years since annexation. It then elaborates on the major conservation concerns at the Prince Edward Island group, and considers actions that have been or should be taken to address these concerns, thus ensuring the continued protection of the group.

\section{I The evolving management of the islands}

A growing appreciation of the intrinsic ecological value of the Prince Edward Islands has been reflected by the increasing levels of protection afforded to them over the years (Cooper \& Condy 1988; Visagie 1988; Cooper 1995a; PEIMPWG 1996). This protection has come in the form of national legislation, and through international instruments to which South Africa is a party (Table 12.1). After annexation in 1948, the islands (extending to the low-water mark) were first administered by the Department of Transport. They are currently managed by the South African Department of Environmental Affairs and Tourism (henceforth referred to as the Department). In 1985 this department, then the Department of Environment Affairs, took over as the management authority of the island group. The islands were administered in an essentially ad hoc manner for the first four decades following their annexation, with no formal document setting out management procedures. In 1982, a "Code of Conduct for the Environmental Protection of the Prince Edward Islands" was developed (Visagie 1988). This was formally adopted in 1988 (Cooper \& Condy 1988) and the islands were managed according to this code of conduct until the adoption of the first management plan in 1995 (see below). Although the islands' seals and seabirds were (and still are) protected by the Sea Birds and Seals Protection Act (Act No. 46 of 1973), the islands were only accorded formal nature reserve status in November 1995, when they were declared a Special Nature Reserve (equivalent to the World Conservation Union's Protected Area Management Category Ia: area managed mainly for science or wilderness protection), in terms of the Environmental Conservation Act (Act No. 73 of 1989) (Cooper 1995a; PEIMPWG 1996; Hänel \& Chown 1998). 
Table 12.1 Protection offered to the Prince Edward Islands and surrounding waters by national legislation and international agreements (adapted from Chown et al. 2006).

\begin{tabular}{|c|c|c|}
\hline & International agreement & National legislation \\
\hline \multirow{8}{*}{$\begin{array}{l}\text { Terrestrial } \\
\text { and Marine } \\
\text { Environment }\end{array}$} & Convention on Biological Diversity (CBD) & $\begin{array}{l}\text { Environment Conservation } \\
\text { Act (No. } 73 \text { of 1989) }\end{array}$ \\
\hline & $\begin{array}{l}\text { Convention on the Conservation of } \\
\text { Antarctic Marine Living Resources } \\
\text { (GCAMLR) }\end{array}$ & $\begin{array}{l}\text { National Environmental } \\
\text { Management Act (NEMA) } \\
\text { (No. } 107 \text { of 1998) and } \\
\text { subsequent amendments }\end{array}$ \\
\hline & $\begin{array}{l}\text { Kyoto Protocol to the United Nations } \\
\text { Framework Convention on Climate } \\
\text { Change }\end{array}$ & $\begin{array}{l}\text { National Environmental } \\
\text { Management: Protected } \\
\text { Areas Act (NEMPAA) } \\
\text { (No. } 57 \text { of } 2003)\end{array}$ \\
\hline & $\begin{array}{l}\text { United Nations Framework Convention } \\
\text { on Climate Change (UNFCGG) }\end{array}$ & $\begin{array}{l}\text { National Environmental } \\
\text { Management: Biodiversity } \\
\text { Act (NEMBA) (No. } 10 \\
\text { of 2004) }\end{array}$ \\
\hline & $\begin{array}{l}\text { Montreal Protocol-Protocol for the } \\
\text { Protection of the Ozone Layer }\end{array}$ & $\begin{array}{l}\text { National Environmental } \\
\text { Management: Air Quality } \\
\text { Act (No. } 39 \text { of 2004) }\end{array}$ \\
\hline & $\begin{array}{l}\text { African Convention on the Conservation } \\
\text { of Nature and Natural Resources } \\
\text { (Algiers Convention) }\end{array}$ & \\
\hline & $\begin{array}{l}\text { Convention on Wetlands of International } \\
\text { Importance especially as Waterfowl } \\
\text { Habitat (Ramsar Convention) }\end{array}$ & \\
\hline & $\begin{array}{l}\text { World Heritage Convention - Convention } \\
\text { Concerning the Protection of the World } \\
\text { Gultural and Natural Heritage }\end{array}$ & \\
\hline \multirow{7}{*}{$\begin{array}{l}\text { Marine } \\
\text { environment } \\
\text { only }\end{array}$} & $\begin{array}{l}\text { Convention on Prevention of Dumping } \\
\text { of Waste from Ships and Aircraft }\end{array}$ & $\begin{array}{l}\text { Carriage of Goods by Sea } \\
\text { Act (No. } 1 \text { of 1986) }\end{array}$ \\
\hline & $\begin{array}{l}\text { International Convention for the } \\
\text { Prevention of Pollution from Ships } \\
\text { (MARPOL) }\end{array}$ & $\begin{array}{l}\text { Dumping at Sea Control Act } \\
\text { (No. } 73 \text { of 1980) }\end{array}$ \\
\hline & $\begin{array}{l}\text { Paris Convention on Prevention of } \\
\text { Marine Pollution from Land-based } \\
\text { Sources }\end{array}$ & $\begin{array}{l}\text { Hazardous Substances Act } \\
\text { (No. } 15 \text { of 1973) }\end{array}$ \\
\hline & $\begin{array}{l}\text { United Nations Convention on the } \\
\text { Law of the Sea }\end{array}$ & $\begin{array}{l}\text { Marine Living Resources Act } \\
\text { (No. } 18 \text { of 1998) }\end{array}$ \\
\hline & $\begin{array}{l}\text { Agreement for the Implementation of } \\
\text { the Provisions of the United Nations } \\
\text { Convention on the Law of the Sea }\end{array}$ & $\begin{array}{l}\text { Marine Pollution (Prevention } \\
\text { of Pollution from Ships) Act } \\
\text { (No. } 2 \text { of 1986) }\end{array}$ \\
\hline & & $\begin{array}{l}\text { Maritime Zones Act } \\
\text { (No. } 15 \text { of 1994) }\end{array}$ \\
\hline & & $\begin{array}{l}\text { National Environmental } \\
\text { Management: Coastal Zone } \\
\text { Management Bill }\end{array}$ \\
\hline
\end{tabular}


Table 12.1 Continued.

\begin{tabular}{|c|c|c|}
\hline & International agreement & National legislation \\
\hline \multirow{8}{*}{ Species } & $\begin{array}{l}\text { Agreement on the Conservation of } \\
\text { Albatrosses and Petrels (2004) }\end{array}$ & $\begin{array}{l}\text { Sea Birds and Seals } \\
\text { Protection Act (No. } 46 \\
\text { of 1973) }\end{array}$ \\
\hline & $\begin{array}{l}\text { Bonn Convention - Convention on the } \\
\text { Conservation of Migratory Species of } \\
\text { Wild Animals (CMS) }\end{array}$ & $\begin{array}{l}\text { Marine Living Resources Act } \\
\text { (No. } 18 \text { of 1998) }\end{array}$ \\
\hline & Convention on Biological Diversity (CBD) & $\begin{array}{l}\text { National Environmental } \\
\text { Management: Biodiversity } \\
\text { Act (NEMBA) (No. } 10 \\
\text { of 2004) }\end{array}$ \\
\hline & $\begin{array}{l}\text { Convention on the Conservation of } \\
\text { Antarctic Marine Living Resources } \\
\text { (CGAMLR) }\end{array}$ & $\begin{array}{l}\text { Seabirds, Shorebirds and } \\
\text { Seals Conservation Act } \\
\text { (in draft form) }\end{array}$ \\
\hline & $\begin{array}{l}\text { Convention for the Conservation of } \\
\text { Antarctic Seals }\end{array}$ & \\
\hline & $\begin{array}{l}\text { Convention on International Trade in } \\
\text { Endangered Species of Wild Fauna and } \\
\text { Flora (GITES) }\end{array}$ & \\
\hline & $\begin{array}{l}\text { International Convention for the } \\
\text { Regulation of Whaling (IWC) }\end{array}$ & \\
\hline & $\begin{array}{l}\text { International Plan of Action for Reducing } \\
\text { Incidental Catch of Seabirds in Longline } \\
\text { Fisheries of the Food and Agricultural } \\
\text { Organization of the United Nations (FAO } \\
\text { IPOA-Seabirds) }\end{array}$ & $\begin{array}{l}\text { National Plan of Action for } \\
\text { Reducing Incidental Catch } \\
\text { of Seabirds in Longline } \\
\text { Fisheries (in draft form) }\end{array}$ \\
\hline \multirow{2}{*}{$\begin{array}{l}\text { Cultural } \\
\text { Heritage }\end{array}$} & $\begin{array}{l}\text { World Heritage Convention - Convention } \\
\text { Concerning the Protection of the World } \\
\text { Cultural and Natural Heritage }\end{array}$ & $\begin{array}{l}\text { National Heritage Resources } \\
\text { Act (No. } 25 \text { of 1999) }\end{array}$ \\
\hline & & $\begin{array}{l}\text { Maritime Zones Act (No. } 15 \\
\text { of 1994) }\end{array}$ \\
\hline
\end{tabular}

Since 1996, theislands have been environmentally managed by the Department's Directorate: Antarctica \& Islands, acting on the advice of the Prince Edward Islands Management Committee and according to the Prince Edward Islands Management Plan (PEIMPWG 1996). The objectives of this first management plan reflected the current emphasis on conservation and research and included the maintenance of biological diversity, the minimisation of interference with natural processes and of the destruction or degradation of natural and historical features, the encouragement of activities aimed at restoring and rehabilitating damage due to local human activities, the encouragement of research supporting these aims, and the creation of an awareness of the value and fragility of the islands' ecosystems (PEIMPWG 1996).

From the end of 2007 (when the term of the current management committee expires) the management of the islands will follow the provisions of a new 
environmental management plan produced under contract (Chown et al. 2006), which currently (June 2007) has been accepted by the Department but not yet formally adopted by the Minister of Environmental Affairs and Tourism (C.A. Jacobs, personal communication). The new plan aims to ensure the ongoing protection and conservation of the islands by providing a comprehensive set of management provisions. It is much more detailed than its predecessor, following principles set out in the ISO 14000 Environmental Management Systems Standards that require harmful effects on the environment to be minimized. Significantly, it also aims to achieve continual improvement in environmental performance. The new management plan will thus be an evolving document that can be updated piecemeal as new understandings and findings are made by a process of "adaptive management." This process will be supported by regular reviews and auditing procedures, taking into account best practice as developed elsewhere in the world but especially at other Southern Ocean islands (see De Villiers et al. 2006a). The new plan sets out in detail provisions for management in terms of administration, biodiversity conservation, historical conservation and waste management (Chown et al. 2006). It defines five management zones and the activities that may take place in these, with access defined according to a permitting system. On Marion Island there is a Service Zone around the base (high level of human traffic) and a Natural Zone near the base and at the field huts (limited free walking). The rest of the island is defined as a Wilderness Zone (no general access), except for certain areas sensitive to human interference which are defined as Limited Access Zones (access to scientists and support personnel of approved projects only). All of Prince Edward Island is defined as a Protected Zone, with strict limits on the frequency and duration of visits, and the number of visitors (Chown et al. 2006).

In June 2006, a process began whereby responsibility for environmental management at the Prince Edward Islands was handed over by the Department's Directorate: Antarctica \& Islands to its Directorate: Environmental Impact Management, to which new staff have been appointed (C.A. Jacobs, personal communication). The exact new management structure is still to be elucidated, but it is expected that the existing management committee will be replaced by a Prince Edward Islands Management Authority, appointed by the Minister in terms of the National Environmental Management: Protected Areas Act (Act No. 57 of 2003). Unlike the current management committee, the role of which was purely advisory, the management authority will have the functions of management (including the issuing of permits) and the evaluation of research proposals (PEIMPWG 1996; Chown et al. 2006). However, following the provisions of the act's regulations, the new management plan allows for the management authority to appoint one or more committees of experts to advise it, by way of inviting nominations from interested and affected parties (Chown et al. 2006). 
Although the National Environmental Management: Protected Areas Act upholds the Special Nature Reserve status of the Prince Edward Islands, the National Environmental Management: Biodiversity Act (Act No. 10 of 2004) is also of particular relevance to the management of the islands. This act allows for the management authority of the islands to produce biodiversity management plans for threatened species and bioregional plans, to manage threatening processes at the islands (in particular, it requires the listing of invasive species) and to ensure the monitoring of biodiversity.

Increased concern for the islands is also evidenced by the requirement (formal since 1995) for Environmental Impact Assessments (EIAs) to be performed prior to any major construction or human activity (PEIMPWG 1996; Chown et al. 2006). No EIA was undertaken for the construction of the existing meteorological base on Marion Island, or for the many subsequent enlargements and reconstructions of this facility. Similarly, no EIAs were performed for the placement (and replacement) of field huts from 1974 onwards, or for the failed hydro-electric scheme constructed in the 1980s. The first EIA conducted was for the abortive proposal in the 1980s to establish an emergency landing facility for fixed-wing aircraft on Marion Island (Heymann et al. 1987). The construction of a new and modern research facility to replace the old base on Marion Island commenced in 2003. A scoping document, broadly equivalent to an EIA, was produced for the replacement research base which is still under construction (Environomics 2002). An EIA will be required for the decommissioning of the current base and its associated structures, and for the positioning of new field huts planned to take place in 2007 (C.A.Jacobs, personal communication).

Public awareness and co-operation is of utmost importance in the conservation of the Prince Edward Islands. Copies of the 1996 management plan and a visitors' guide (Hänel \& Chown 1998) are made available to all visitors on board vessels bound for the islands, and at the base on Marion Island. A Conservation Officer, appointed on the recommendation of the management committee, accompanies relief voyages to the island and presents an on-board talk to all expedition members, highlighting the major conservation issues and ways in which these are addressed. The Conservation Officer is on hand to answer conservation-related questions during the time spent on Marion Island, and to ensure that visitors to the island adhere to their permit conditions. Codes of conduct are also described in the visitor's guide (Hänel \& Chown 1998). The revised management plan addresses the raising of awareness among visitors to the islands, the training and education of personnel involved at the islands, and stresses the importance of ongoing capacity building (Chown et al. 2006). A member of each over-wintering team is also appointed a Conservation Officer, responsible for conservation issues outside the periods of annual relief voyages. 


\section{I2.2 Major conservation concerns at the islands}

\subsection{Introductions of alien species}

One of the greatest threats to biodiversity is that of biological invasion. There is a clear link between the number of alien species present on Southern Ocean islands and the number of human visitors over the last 200 years (Chown et al. 1998). Alien microbes, fungi, plants or animals occur on all sub-Antarctic islands and their introductions have been associated with the movement of people and cargo in connection with research and commercial and tourist activities (Frenot et al. 2005). In the five decades since the first terrestrial biological research expedition to the Prince Edward Islands in 1965, 63 teams have stayed for varying periods on Marion Island and various other expeditions have been made to the island group. The construction of the new research base on Marion Island, beginning in 2003, was associated with an increase in the number of annual voyages, personnel and supplies to that island. There has also been interest expressed in the islands by tour companies, with three applications for visits made in the 1990s (Heydenrych \& Jackson 2000) and one offshore cruise made into the islands' territorial waters in 2002 (P.G. Ryan, personal communication). Land-based tourism is, however, prohibited in terms of the islands' current Special Nature Reserve status and the National Environmental Management: Protected Areas Act.

The Prince Edward Islands have experienced a number of introductions of alien species (e.g. Gremmen 1975; Watkins \& Cooper 1986; Gremmen \& Smith 1999; Chown et al. 2002; Frenot et al. 2005). These have been most numerous on Marion Island, which has received the majority of the human visitors to the island group (no base or field huts are present on Prince Edward Island). Most introductions occurred shortly after annexation in 1948, when maintaining a political presence rather than conservation was the focus of human activity at the islands. Several introductions were deliberate, such as that of German Merino Sheep Ovis aries in 1959 and Brown Trout Salmo trutta in 1964 (Watkins \& Cooper 1986). Some were made through ignorance or lack of forethought, or by accident. For example, the House Mouse (Mus musculus domesticus, Jansen Van Vuuren \& Chown 2007) was introduced to Marion Island in the early 1800s and the aggressive invading grass, the Creeping Bent Agrostis stolonifera, was most probably introduced with sheep fodder and first noticed on the island in 1965 (Watkins \& Cooper 1986; Cooper 1995b; Cooper 2008) (Table 12.2). One of the most devastating deliberate introductions was that of the Domestic Cats Felis catus in 1949, in an attempt to control the House Mouse population at the meteorological base on Marion Island (Cooper 2008). The cats became feral and this resulted in the deaths of many thousands of burrowing petrels (Cooper \& Fourie 1991; Cooper et al. 1995) (Table 12.2). 


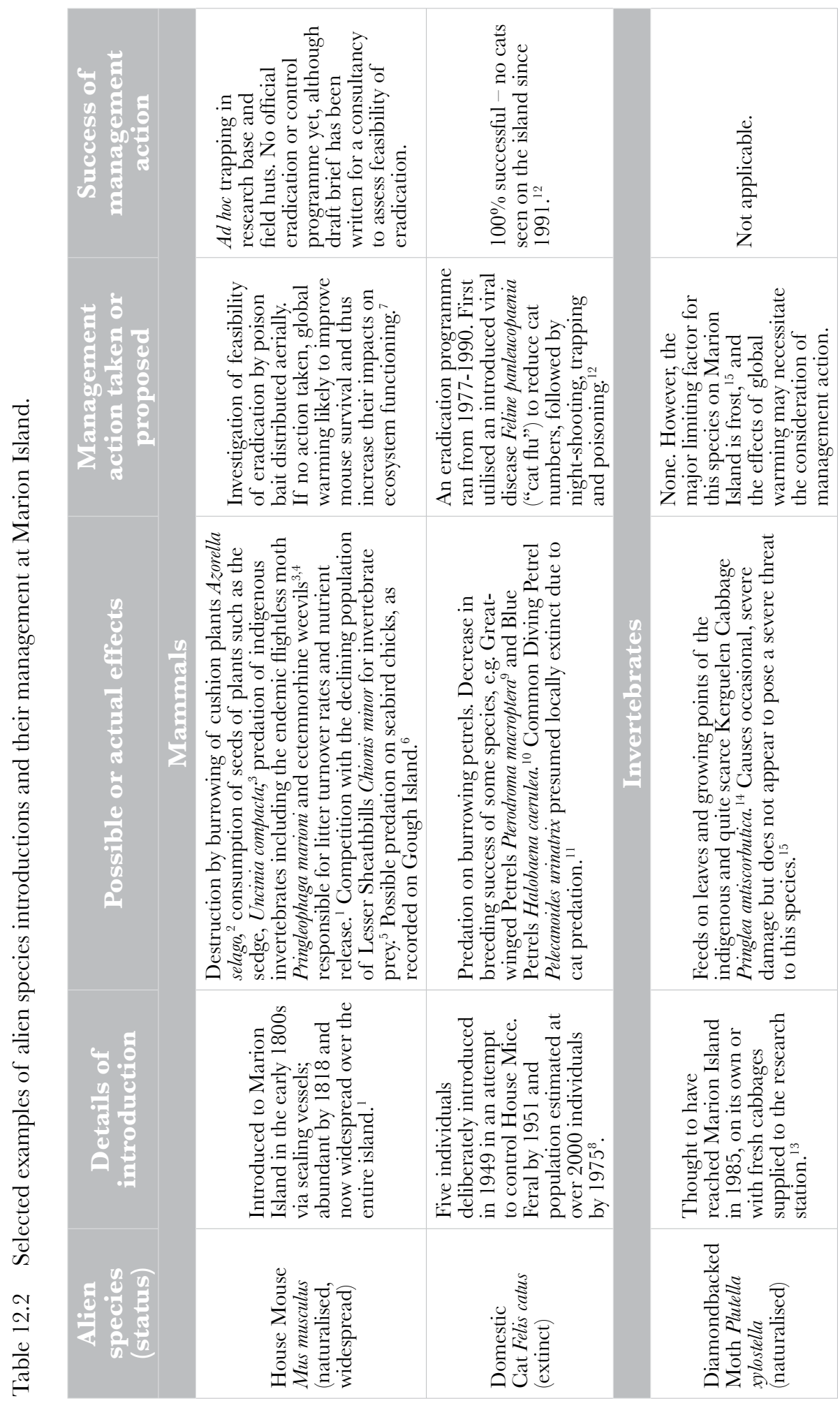




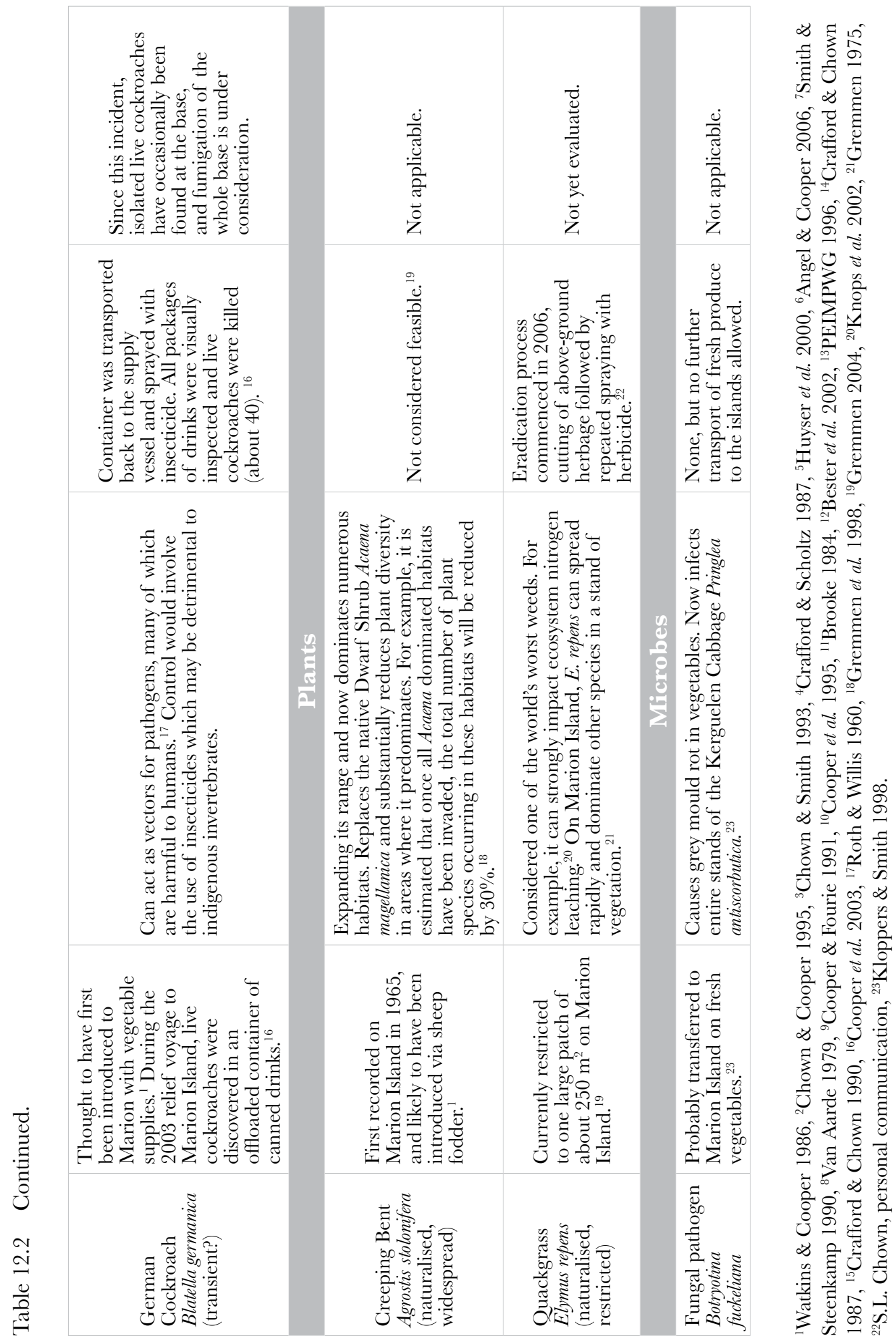

CONSERVATION AND MANAGEMENT 
Since the 1970s, with an increased awareness of the potential impacts of introduced non-native biota, attempts have been made to eradicate established alien species from Marion Island (Cooper et al. 2003). In 1984, Brown Trout were removed from the Van den Boogaard River (Cooper et al. 1992). Feral cats were eradicated in 1991, after a lengthy and sustained effort that began in 1977 (Bester et al. 2002, Table 12.2). Currently, there is a focus on the eradication or control of small, localized populations of the alien grass Red Top Agrostis gigantea (Gremmen \& Van der Meijden 1995; Gremmen \& Smith 1999; Slabber \& Chown 2002). In 2006, a concerted effort was initiated to eradicate an isolated stand of Quackgrass Elymus repens at the site of a camp established near a shipwreck at Ship's Cove on the eastern side of the island (S. Kritzinger-Klopper \& S.L. Chown, unpublished data, Plate 12.1). A plan for the management of alien vascular plants on the Prince Edward Islands has been drawn up (Gremmen 2004) and the Department's Directorate: Environmental Impact Management intends to appoint an Aliens Officer on the over-wintering team on Marion Island to continue the process of alien plant control. A feasibility study has been commissioned to investigate the eradication of the House Mouse from Marion Island and a pilot study on the likely effects of poison bait on selected non-target species was undertaken in August 2006 (J. Cooper, unpublished data). However, eradication efforts of alien species are likely to be hampered by the effects of climate change. Warmer climates will not only facilitate the establishment of alien species, but will also enable already-established species to expand their ranges and to aggravate their effects on local species and ecosystems (Pakhomov \& Chown 2003).

The eradication of established alien organisms is costly, time-consuming and labour-intensive. For some species on the Prince Edward Islands, eradication is being considered, e.g. for the House Mouse on Marion Island. For others, it is simply not considered feasible, e.g. for the well-established Creeping Bent and the slug Deroceras panormitanum on Marion Island, and Procumbent Pearlwort Sagina procumbens on both Marion and Prince Edward Islands (Cooper et al. 2003; Ryan et al. 2003; Gremmen 2004). The prevention of new alien species introductions is therefore of paramount importance for the continued conservation of the islands. Prince Edward Island is one of the most pristine of the Southern Ocean Islands, having never supported any alien vertebrate species and currently only supporting three species of alien vascular plants and very few known alien invertebrates (Chown et al. 1998; Ryan et al. 2003; Hugo et al. 2006). Because of the link between the number of alien species introductions and the number of human visitors (Chown et al. 1998), the first management plan restricted visits to Prince Edward Island to only one a year, by up to six people, for a maximum of four days per visit. The new management plan calls for a limit on visits to one every two years, by a maximum of 10 people for a maximum duration of eight days (Chown et al. 2006). Overnight access to Marion Island will be restricted by the number of beds available at the base, i.e. 80, when the construction of the new base is completed. 
In recent years, there has been a dramatic increase in the stringency of the quarantine procedures followed during visits to the islands, on the advice of the management committee (Cooper et al. 2003). Quarantine measures are especially strict for Prince Edward Island (Cooper et al. 2003; Chown et al. 2006), due to its relatively pristine state. These and other procedures have now been formally incorporated into the revised management plan (Chown et al. 2006). In an attempt to raise awareness regarding the dangers of alien introductions and to eliminate personal gear as a source of introductions, all visitors to the islands participate in a compulsory "Boot-washing Ceremony" aboard the vessel on southbound journeys, whereby all protective clothing and field gear is inspected and cleaned (Plate 12.2). Particular attention is paid to cargo items which have the potential to act as vectors for alien species (de Villiers et al. 2006b) - cargo containers bound for the sub-Antarctic have been found to harbour spider webs, seeds and other plant material (Whinam et al. 2005). Fresh produce on the islands is prohibited - leafy vegetables, especially, can harbour substantial numbers of invertebrates such as aphids, spiders, moths, beetles, nematodes and even snails. Fresh vegetables were probably the source of the fungal pathogen Botryotina fuckeliana, which has infected the Kerguelen Cabbage Pringlea antiscorbutica on Marion Island (Kloppers \& Smith 1998). Due to concern over potential human-assisted introductions of avian diseases to the bird populations at the Prince Edward Islands, various restrictions are in effect regarding poultry products. These include a ban on all poultry products on Prince Edward Island. On Marion Island, only canned poultry products may be used at field huts and only canned, de-boned or irradiated (eggs) poultry products at the base (de Villiers et al. 2006a). The revised management plan calls for a complete ban on eggs at both islands (Chown et al. 2006). The risk of transmitting bovine tuberculosis and other contagious diseases through dairy products will be minimised by only allowing pasteurised and sterilised dairy products on the supply vessel and on the islands (Chown et al. 2006).

One major potential source of contamination during sub-Antarctic voyages is the transport used for ship-to-shore transfers (Whinam et al. 2005). Vessels and helicopters bound for the Prince Edward Islands are thoroughly checked. However, little is as yet known about the actual or potential transfer of littoral organisms from the supply vessel's hull or ballast water tanks to the waters surrounding the Prince Edward islands, although the potential for this does exist (e.g. Lewis et al. 2003). Although ballast water is typically not discharged at the islands, this might be a concern during the decommissioning of the old base, when an unloaded vessel will take on several tonnes of cargo at the island. More significantly, recent work has identified substantial hull-fouling communities on the Antarctic research/supply vessel S.A. Agulhas, which ordinarily undertakes the annual relief voyages to Marion Island, and large populations of the invasive mussel, Mytilus galloprovincialis, in its sea chests (Lee \& Chown 2007). 
The construction of the new research base on Marion Island, which commenced in 2003, has resulted in an additional three voyages per year to Marion Island by the S.A. Agulhas until construction is completed. Associated with these extra voyages are an increase in the number of visitors and in the type and quantity of provisions and supplies taken to the island. This has created new opportunities for the introduction of alien species to the island, a fact which was recognized in the scoping study for the new facility (Environomics 2002). Project Environmental Officers are appointed for each voyage during the construction phase and strict quarantine procedures are in place for construction voyages. As part of the intended decommissioning of the old base, there is to be an emphasis on site rehabilitation (including the reestablishment of natural vegetation on the site and the prevention of further spreading of alien species from it), following a comprehensive Environmental Impact Assessment (Environomics 2002).

Despite the quarantine measures now associated with voyages to the islands, previously unrecorded alien invertebrates and plants are still intermittently discovered at Marion Island. Recent introductions have mostly been found in the vicinity of the base (Hänel et al. 1998; Gremmen \& Smith 1999). During the 2003 relief voyage to Marion Island, for example, live German Cockroaches Blatella germanica were discovered in offloaded containers of canned drinks (Cooper et al. 2003). The cockroaches were transported to the island in the cardboard packaging holding the cans, and are believed to have originated from the premises of the supplier in Cape Town. Despite a seemingly successful effort to deal with this invasion at the time, cockroaches have been occasionally found in the base buildings during or shortly after relief visits. Although incidents such as this usually involve only one or a few organisms, occasionally larger numbers of organisms are involved. For example, large numbers of House Crickets Gryllus bimaculatus were present on board the S.A. Agulhas during its southbound voyage to Marion Island in 2002. Emergency efforts to locate and kill individuals included a thorough wash-down of the vessel's decks and outer spaces (now recommended as a routine procedure for southward voyages), and none of the insects apparently survived to find their way onto the island (J. Cooper, unpublished data). By contrast, an isopod, Porcellio scaber, and a parasitic wasp, Aphidius matricariae, have established recently (Slabber \& Chown 2002; Lee et al. 2007). In 2004, several seeds of the Australian invasive tree, Rooikrans (or Red Eye) Acacia cyclops were discovered in the ship's hold during a construction voyage. Although the holds were subsequently fumigated with Methyl Bromide, a trial revealed that this treatment did not prevent germination of the seeds (M.S. de Villiers, unpublished data). In October 2006 an alien plant, tentatively identified as Cats-ear Hypochoeris radicata, was discovered at one of the field huts on Marion Island (S.L. Chown, personal communication). Hypochoeris radicata was first collected on the island in 1953 and had last been seen in 2002 (Gremmen 2004). The death of approximately two thousand Macaroni Penguins Eudyptes chrysolophus in 2004 (Plate 12.3) was 
probably due to disease, as the necropsy of two affected birds indicated the presence of Avian Cholera Pasteurella multocida (Crawford et al. 2005).

Human passage through dense seabird breeding colonies has the potential to spread parasites and pathogens from one colony to another, and this incident led to the drafting of procedures to be followed in the event of future disease outbreaks (R.J.M. Crawford, personal communication). These prioritise the prevention of the spread of pathogens to other colonies by restricting access to affected colonies to scientists performing essential research, and by requiring such scientists to disinfect their outer protective clothing and footwear before moving on to other locations. The new management plan lists actions to be taken in the case of unusual wildlife mortalities, and calls for the drafting of a disease contingency plan by the islands' management authority (Chown et al. 2006).

Each incident of an alien species introduction identifies shortcomings in existing quarantine procedures and suggests improvements. Currently, these are discussed at management committee meetings, resulting in the ongoing development of effective quarantine procedures. This process is assisted by increased awareness on the part of the islands' management committee, researchers, support personnel and construction teams. However, it is recognized that such ad hoc responses to imminent or actual introductions are not ideal, and a comprehensive risk assessment was commissioned along with the updating of the management plan. The new plan includes a risk assessment framework (including species, vector and pathway risk assessments), as required under the National Environmental Management: Protected Areas Act.

\subsubsection{Factors affecting marine resources}

The most serious threat for many species of albatross and petrel is that of mortality associated with commercial longline fishing operations (Gales 1998). The Prince Edward Island group is an important breeding locality for nine affected species (five species of albatrosses and four species of large petrels of the genera Macronectes and Procellaria), all of which are listed as threatened or near-threatened by the World Conservation Union, and are also listed within the Agreement on the Conservation of Albatrosses and Petrels, of which South Africa is a founding Party (Cooper \& Ryan 2001; BirdLife International 2004). The legal Patagonian Toothfish Dissostichus eleginoides fishery began in the islands' territorial waters and Exclusive Economic Zone in 1996, but illegal vessels had already been operating in the region for some time and this resulted in the near-collapse of the fishery (Pakhomov \& Chown 2003). Large numbers of seabirds were estimated to have been killed on longline hooks during the first fishing season, largely due to high numbers of illegal vessels which were unlikely to be employing effective mitigation measures to prevent this (Nel et al. 2002a). The pelagic tuna Thunnus spp. fishery is the largest longline fishery in the Southern Ocean and trends in the breeding population sizes of four large procellariiform seabirds at Marion Island are matched by changes in effort by this fishery in the southern Indian Ocean (Nel et al. 2002a). Apart from 
being a primary cause of adult mortality, fisheries may have subtle impacts on seabird populations which may only become apparent over the long-term. For example, gender differences in the foraging ranges of Grey-headed Albatrosses Thalassarche chrysostoma and Wandering Albatrosses Diomedea exulans may result in differential mortality by longline fishing vessels of males and females, and this may ultimately alter the demographic structure of populations ( $\mathrm{Nel}$ et al. 2000; Nel et al. 2002b).

In terms of the Marine Living Resources Act of 1998, no fishing is permitted inside an exclusion zone around the islands (Table 12.1). The recent extension of this zone from eight to 12 nautical miles, to include all of the territorial waters (T. Akkers, personal communication), offers full protection to the shallow waters linking the islands, to their biota, and to those seabird species affected by longlining. Protection is also enhanced for several declining populations of inshore-foraging seabirds, such as the Crozet Shag Phalacrocorax [atriceps] melanogenis and the Gentoo Penguin Pygoscelis papua (South Africa 2005). South Africa has drafted a National Plan of Action for Reducing Incidental Catch of Seabirds in Longline Fisheries (NPOA-Seabirds (Cooper \& Ryan 2003; refer Table 12.1) in terms of guidelines set out by the Committee on Fisheries of the Food and Agriculture Organization of the United Nations (FAO). One of the aims of the draft plan is the reduction of seabird mortality from longlining around the Prince Edward Islands. Interim measures to reduce longline mortalities currently in place follow those adopted by the Commission for the Conservation of Antarctic Marine Living Resources (CGAMLR), of which South Africa is a member. These include only setting lines at night, weighing lines to maximize sinking rates, not dumping offal during setting, keeping deck lighting to a minimum, and using bird-scaring lines during setting. These measures have proved successful and, in combination with the progressive movement of fishing activities away from the islands over the years and the presence of observers on board legal vessels, contributed to a decrease in rates of seabird bycatch between 1996 and 2000 from 0.19 to 0.034 birds per 1000 hooks (Nel et al. 2002c). Mortality has remained low in subsequent years (B.P. Watkins, personal communication).

The declaration of a large Marine Protected Area (MPA) around the islands is now under active consideration following a Ministerial announcement, and this will vastly expand the marine area that is legally protected (South Africa 2005; Lombard et al. 2007). This area is expected to include all territorial waters out to 12 nautical miles and at least some parts of the Exclusive Economic Zone out to 200 nautical miles, and will lead to the creation of one of the world's largest MPAs (South Africa 2005). The MPA will not only contribute to a national system of MPAs and to a developing network of MPAs within the Southern Ocean (including the existing marine reserves around the Australian islands of Macquarie and Heard and McDonald and New Zealand's Auckland Islands), but will also contribute to the recovery of the Patagonian Toothfish and will reduce bird bycatch by the toothfish fishery, particularly of 
albatrosses and petrels (Lombard et al. 2007). Furthermore, the MPA will allow for improved control of both legal and Illegal, Unreported and Unregulated (IUU) fishing. Currently, patrols of the waters around the islands to deter IUU fishing are carried out by naval and fisheries vessels. Three management zones are proposed within the MPA: four IUCN Category Ia reserves (13\% of EEZ), two Conservation Zones (21\% of EEZ) and three Category IV reserves in which regulated fishing will be allowed (remainder of the EEZ). The island group's ecosystems are hugely influenced by the relative positions of the subAntarctic Front and the Antarctic Polar Front. The proposed boundaries of the MPA will traverse latitudinal and longitudinal gradients, thus maximizing opportunities for incorporating the shifting position of these two oceanic fronts, which are critical to the offshore component of the Prince Edward Islands' ecosystem (Lombard et al. 2007). The declaration of the Marine Protected Area will also extend legal protection to cover the foraging ranges of a larger suite of seals and seabirds that breed on the Prince Edward Islands, and will offer protection to benthic and pelagic marine species of both deep waters and of sea mounts (South Africa 2005). However, even this extended protection will not cover the non-breeding ranges of many of the islands' pelagic predators, and will also not cover the foraging ranges during breeding of the more mobile species, such as the Wandering and Grey-headed Albatrosses and the Southern Elephant Seal Mirounga leonina.

Climate change has affected oceanic regimes, which have in turn changed the availability of seal and seabird prey close to the islands. Between 1969 and 1999, sea-surface temperature at Marion Island increased by $1.4^{\circ} \mathrm{C}$ (Mélice et al. 2003) and air temperature increased by $1.2^{\circ} \mathrm{C}$ (Smith 2002). The increase in sea-surface temperature may be related to a southerly shift in the mean position of the Sub-Antarctic Front, with the resultant advection of zooplankton and micronekton to the islands benefiting pelagic predators, but creating unfavourable feeding conditions for inshore feeders (Pakhomov \& Chown 2003). Decreased food availability as a result of climate change has been implicated in the decline of three inshore-foraging species at the Prince Edward Islands: the Gentoo Penguin, Rockhopper Penguin E. chrysocome and Crozet Shag (Crawford et al. 2003a, 2003b, 2004). Climatic perturbations on a global scale may also influence breeding by seabirds, as evidenced by a marked difference in the breeding success of inshore and offshore foragers in 1997/1998, a season coinciding with a major El Niño Southern Oscillation event (Crawford et al. 2003c, 2004).

\subsubsection{Litter, pollution and waste management}

Conservation practices to deal with or prevent pollution were first outlined in 1988 (Cooper \& Condy 1988) and were later described in the islands' first management plan (PEIMPWG 1996). These are summarised in de Villiers et al. (2006a) and have been elaborated in the revised management plan. 
The principles of the waste-management practices outlined in the latter are to ensure that activities on the islands do not result in pollution, damage to the environment or the build up of waste, to reduce amounts of waste, and to consider waste storage, disposal and removal, including recycling and the reduction of waste at source (Chown et al. 2006). Waste-management practices for Prince Edward Island are especially stringent. Current waste-management practices at the islands have been the subject of a recent study (R. Kutranov, unpublished data).

Permanent onshore infrastructure is minimal on the Prince Edward Islands. No artificial structures currently exist on Prince Edward Island, whereas on Marion Island human activities are concentrated at the base and at eight field huts located around the island. There are, however, several obsolete structures on Marion Island, such as the derelict buildings and other structures associated with a disused hydro-electric scheme and the remains of several old field huts. The clearing of these sites is well-advanced and is expected to be completed as part of the decommissioning of the old base. It is a longstanding practice during the annual relief voyage for all onshore personnel to assist in a "chicken run," whereby the area around the base is cleared of all visible litter. Furthermore the Conservation Officer, with the aid of volunteers, undertakes "country cleanups," removing litter, rubble and defunct items such as aerial and marker poles at various field sites that have been earmarked for this purpose during annual relief visits (Plate 12.4). It is roughly estimated that about 20 tonnes of assorted materials have been removed in this way since 2002 (J. Cooper, unpublished data). This practice first began in 1992, when various construction materials were removed from the site of the small water-supply dam on the island (Cooper 1995a). All collected materials are removed from the island to continental South Africa for disposal. The new management plan calls for the continuation of such site cleanups, as well as for site rehabilitation according to an approved restoration plan (Chown et al. 2006). Researchers are also required to provide updated lists with GPS co-ordinates of all field markers, and unrecorded field markers are usually removed as they are encountered by Conservation Officers.

Currently, sewage at the base is not treated and is discharged directly into the sea. This will also be the practice at the new base, but it is intended that sewage will be held in a holding tank and only discharged into the sea after dark. The sewage will then be rapidly diluted by wave action and currents, and any concentration of solid content will be disseminated before daylight (Environomics 2002). Food waste (excluding poultry products, meat bones and cooking oil) is discharged directly into the ocean after dark to deter birds from scavenging from the offal, although giant petrels Macronectes spp. still scavenge at the waste disposal point (L. Clokie, personal communication). At the new base, it is intended that solid kitchen waste will first be macerated and flushed into a holding tank, to be discharged in the same way as sewage (Environomics 2002). 
Packaging of supplies to the island is minimized as far as possible. Plastics, glass and metals are separated, separately containerized and shipped to South Africa for recycling (PEIMPWG 1996; Chown et al. 2006). Relatively low levels of chlorinated hydrocarbons have been found in birds' eggs collected at Marion Island in the past. However, a recorded increase in the levels of certain chemicals in the eggs of scavenging species was postulated to have as its source plastics incinerated at the base (Gardner et al. 1985). The incineration of plastics is no longer practiced. Non-toxic paper and cardboard waste is burnt in an outside incinerator on wind-free days, and the ash is collected and stored for shipment. It is intended that the new base will be supplied with a hightemperature incinerator to minimize atmospheric pollution. Investigations are underway to provide only biodegradable cleaning products for the new base. No other chemicals or hazardous wastes are disposed of through the wastewater system - these are stored separately in clearly marked containers for removal from the island. At field huts, human and food waste accumulates in shallow excavated pits (Plate 12.5) but the installation of alternative methods of sewage disposal is planned to coincide with the placement of the new field huts, probably in 2007 (A. Dreyer, personal communication). All other hut wastes are stored in sealable containers and transported directly back to the supply vessel by helicopter during annual relief voyages, for disposal in South Africa. On the construction site for the new research base, dedicated wastedisposal technicians keep the site free of litter, and the site is inspected daily when a Project Environmental Officer is present on the island. The burning of construction waste was initially prohibited (Environomics 2002) although large quantities of wooden packing material are permitted to be burnt on the island as a cost-saving exercise during construction of the new base. It is intended that the decommissioning of the old base will involve the complete removal of all structures as far as is feasible and as prescribed by an EIA (A. Dreyer, personal communication).

In 1980, several hundred Rockhopper Penguins died at Marion Island following the deliberate dumping of water-contaminated diesel fuel into the sea from the base (Williams 1984). Current procedures and attitudes make a recurrence of such an incident highly unlikely. Ship-to-shore transfer of diesel fuel is carefully monitored from an inflatable dinghy and the hose is pressure-tested before use. The fuel line on the island is regularly inspected for leaks and has internal valves at 30-m intervals to prevent the possibility of major spills. The supply vessel and base carry biodegradable fuel dispersant in case of spills. On shore, generator oil, diesel and other fuel waste are stored in drums which are shipped back to South Africa. The disposal of oil and other harmful substances by vessels visiting the islands is controlled by several regulations (Table 12.1). As yet, the islands have been unaffected by major oil spills such as those which have affected marine life off the South African coast. For example, the sinking of the bulk-ore carrier, the Treasure, near Cape Town in 2000, resulted in the oiling of almost 20000 African Penguins Spheniscus demersus (Nel \& Whittington 2003). Disaster was averted by a successful rehabilitation programme for oiled 
birds and by the temporary relocation of non-oiled birds from the area of the spill, but a similar event near the remote Prince Edward Islands would be catastrophic since there are no necessary materials and facilities on the islands to deal with the effects of a full-scale onshore oil spill. The new management plan calls for the drafting of an oil-spill contingency and rehabilitation plan (Chown et al. 2006).

Marine litter can have severe impacts on marine ecosystems. Plastic litter poses the greatest problem, as it is almost immune to degradation once at sea and can drift for years over vast distances (Ryan \& Moloney 1993). Plastic items showing little sign of degradation are the most abundant type of beach litter (other than wood) found on the Prince Edward Islands (Ryan 1987; J. Cooper, personal observation). Such debris can become colonised by marine biota and assist in the transport of potentially invasive species to new locations through rafting. Although this issue has not been well-studied at the Prince Edward Islands, it has been demonstrated to be a real danger in other parts of the Southern Ocean (Barnes 2002; Barnes \& Fraser 2003). Marine creatures can become entangled in objects such as discarded fishing line, resulting in injuries or the restriction of movement. Entangled individuals of several species of birds (Cooper \& Condy 1988; Nel \& Nel 1999) and all three species of seals (Hofmeyr et al. 2002) that breed on the Prince Edward Islands have been reported. Most of the marine debris found on Marion Island originates from the fishing industry (Ryan 1987; Nel \& Nel 1999). Over the two seasons following the start of the Patagonian Toothfish industry in the Exclusive Economic Zone around the islands, there was a ten-fold increase in the incidence of fishing gear in marine debris at seabird colonies on Marion Island (Nel \& Nel 1999). The incidence of entanglement of fur seals Arctocephalus spp. during a five-year period of long-line fishing in the waters around Marion Island was twice as high as it was during a similar period of time prior to long-line fishing in the region (Hofmeyr et al. 2002). Much larger proportions of wildlife populations ingest marine litter than are entangled by it (Ryan 1996). Ingested debris can cause death or debilitation by obstructing the digestive tract, or by reducing meal size or the urge to eat, and ingested plastic may be a source of toxic chemicals (summarized in Ryan 1990). Specimens of 23 of the 29 species of birds that breed at the Prince Edward Islands were examined and 17 of these were found to have ingested plastic to some degree (from Ryan 1987). Plastic particles were most frequent in Procellariiformes and the Blue Petrel Halobaena caerulea was the worst-affected species, with $92 \%$ of individuals found to have ingested plastic (Ryan 1987).

Several species of birds, notably burrowing petrels, are affected by light pollution associated with human activities at sea and on land. These birds are most active at night and are easily disorientated by bright lights. Especially on misty nights, they are at risk of flying into buildings or other tall structures and being injured (when they become vulnerable to predatory birds such as sub-Antarctic Skuas Catharacta antarctica) or killed. In the Southern Ocean, bird 
strikes on vessels may involve hundreds of birds; for example nearly 900 birds collided with a vessel's superstructure in South Georgia's maritime zone, and 215 of these subsequently died (Black 2005). There are no functioning outside lights at the existing base or huts on Marion Island, and all windows are fitted with black-out blinds which are closed at night. Blinds are also drawn at night on board the supply vessel when it is operating near the islands. Although night-lighting during evening work shifts has been kept to a minimum on the construction site, bird strikes do occasionally occur, e.g. on a misty evening in October 2004, 76 birds (mostly Salvin's Prions Pachyptila salvini) were stunned after flying into buildings (M. Wheeler, unpublished data). Bird strikes also occur at field huts (M.S. de Villiers, personal observation) but the replacement huts will be fitted with window blinds and this should reduce the number of strikes.

\subsubsection{Disturbance}

Human disturbance can reduce the breeding success of impacted species. Disturbance can have obvious, overt effects such as the abandonment of nests by birds and the creation of increased predation opportunities (Anderson \& Keith 1980), or can cause potentially detrimental physiological changes indicated by, for example, increased stress hormone concentrations (e.g. Vleck et al. 2000) or increases in heart rates (e.g. Giese 1998). A reduction in the breeding success of Adélie Penguins Pygoscelis adeliae in Antarctica has been associated with tourist visits (Giese 1996; Woehler et al.1994). Perhaps the most extreme example of the potentially disastrous effects of disturbance is the death of 7000 King Penguins Aptenodytes patagonicus on Macquarie Island, resulting from mass panic following the passage of an aircraft near the colony (Rounsevell \& Binns 1991). On Marion Island, King Penguins at a breeding colony, and non-breeding Gentoo Penguins, also reacted with panic to overflights by a fixed-wing aircraft (Cooper et al. 1994a). Seals may also be sensitive to disturbance associated with aircraft activity (e.g. Born et al. 1999; M.S de Villiers \& J. Cooper, personal observations).

During 1996 and 1997, the Department received three proposals for tourism to sub-Antarctic Marion Island, but none of these proposed visits transpired. An Environmental Impact Assessment (Heydenrych \& Jackson 2000) outlined the potential positive and negative effects of land-based tourism on the island, and provided a list of recommendations should tourism be allowed. However, under the Special Nature Reserve status of the Prince Edward Islands, commercial onshore tourism is prohibited in terms of the National Environmental Management: Protected Areas Act of 2003 (see Table 12.1). In November 2002 the first vessel carrying tourists visited the island's inshore waters, although tourists were not permitted to disembark. Tourism aside, disturbance of wildlife can be caused by researchers, support personnel and logistic flight operations. 
Several species of fauna on Marion Island are known to be especially vulnerable to disturbance and some broad guidelines are in place for their approach. The disappearances of colonies of both Gentoo Penguins (Crawford 1952; Crawford et al. 2003a) and Southern Giant Petrels M. giganteus (Nel et al. 2002a) close to the island's base are thought to have been the result of human disturbance. Breeding colonies of these species are classified as limited access zones (entrance by special permit only), with a minimum approach distance of $100 \mathrm{~m}$, and the management committee has recently recommended that this also apply to colonies of Crozet Shags following the proposal of Crawford et al. (2003b). The numbers of Wandering Albatrosses breeding within $200 \mathrm{~m}$ of the base more than halved within the first two decades of human occupation (deduced from maps published by La Grange 1962; Van Zinderen Bakker Jr. 1971; Grindley 1981), suggesting that this reduction may have been due to human disturbance (Watkins 1987). A recent study has investigated minimum approach distances for key seabird and seal species on Marion Island, and the impacts of various human activities on these species. Research indicates that brooding Wandering Albatrosses approached on foot to less than $10 \mathrm{~m}$ show signs of alarm or aggression (Plate 12.6), reactions that are likely to be preceded by physiological stress responses, and that on Marion Island this species does not appear to have habituated to either researcher disturbance or incidental disturbance by island personnel (De Villiers et al. 2005). Preliminary measurements of heart rates in response to human disturbance indicate that Northern Giant Petrels $M$. halli may be as responsive to human disturbance as Southern Giant Petrels have been found to be at other sites (de Villiers et al. 2006b). Although the latter are colonial breeders and are thus effectively protected by the status of their colonies as limited-access zones on Marion Island, the imposition of large exclusion zones around solitarily breeding Northern Giant Petrels is not practical. Protection against disturbance could be improved by the restriction of human passage through breeding areas to designated paths.

Proposals for research on seabirds and seals on the islands require ethics approval by the relevant institutions undertaking the research. In response to a growing body of evidence that flipper-banding of penguins in the Antarctic and sub-Antarctic may compromise survival (Jackson \& Wilson 2002; Petersen et al. 2005), all flipper-banding of penguins on the Prince Edward Islands halted in 2004 (R.J.M. Crawford, personal communication). Declines in some populations of Gentoo Penguins (Crawford et al. 2003a) and Southern Giant Petrels (Cooper et al. 2001) on Marion Island have been associated with previous intrusive research programmes which were consequently discontinued. Removal of cats from Marion Island resulted in the accidental mortality of some seabirds but had no negative effects on population levels (Bloomer \& Bester 1992; Bester et al. 2002). Small-mammal trapping, as part of studies on the effects of mice on Marion Island, also had insignificant effects on bird populations - only four birds were caught in traps over a total of 46500 trapnights (Cooper et al. 1994b). The removal of animals from the Prince Edward 
Islands for zoological gardens has taken place on several occasions in the past (Cooper 1995a) and the collection of King Penguins for this purpose is likely to take place again (C.A. Jacobs, personal communication).

Although trampling by humans in Antarctic and sub-Antarctic environments is often highly visible, little is known about its ecological effects. An assessment of the impacts of human trampling in three habitats on Marion Island revealed that responses differed, depending on soil characteristics and the structure of the original vegetation (Gremmen et al. 2003). In general, trampling negatively affected species richness and plant cover and tracks were associated with an increase in the number and cover of introduced species (Gremmen et al. 2003). Walkways connect buildings at the existing base and on the construction site for the new base, movement of personnel and the placement of construction material are restricted to temporary walkways laid down for this purpose where possible.

Concerns regarding the impacts of humans at the Prince Edward Islands largely centre on the natural environment. However, there are also concerns over the conservation of the islands' cultural heritage. At least 18 archaeological sites are known on Marion Island, and six on Prince Edward Island (Cooper $\&$ Avery 1986). These mainly date back to the sealing era in the 19th and 20th centuries, and consist of remnants of camps and field huts with associated sealing equipment, notably iron trypots used to render elephant seal blubber (Cooper \& Avery 1986). There are also several known or presumed grave sites and the remains of several shipwrecks. Although the surface exposures of most known sites and artefacts have been described (Cooper \& Avery 1986; Graham 1989; Boshoff et al. 1997; Boshoff \& Van Schalkwyk 1999) and recommendations have been made for their protection and conservation (Graham 1989), no thorough archaeological studies have been undertaken on either island (Cooper 2008). Sites on Prince Edward Island tend to be less disturbed than those at Marion Island, where the extensive removal of souvenirs has taken place in the past. Sites older than 60 years are protected by the National Heritage Resources Act Number 25 of 1999 (Table 12.1) and all have the status of limited access zones in the first management plan (PEIMPWG 1996). All historical sites fall within limited-access zones and no artefacts may be handled. The new management plan calls for an updated inventory of sites and artefacts, followed by the drafting of conservation management plans for heritage resources that are identified as of high value or as being at risk (Chown et al. 2006).

\subsection{Conclusions}

Since the annexation of the Prince Edward Islandsin 1948, considerableprogress has been made in the conservation of the islands' biota, and management practices at the islands have been substantially improved. New initiatives which promise to advance further the conservation of the islands and their resources include a recent successful nomination to the Ramsar Convention 
on Wetlands of International Importance, a pending nomination to the World Heritage Convention, the latter including territorial waters out to 12 nautical miles (Table 12.1), the declaration of a Marine Protected Area around the islands (Lombard et al. 2007), and the revision of the islands' management plan (Chown et al. 2006). The National Environmental Management: Protected Areas Act, passed in 2004, also improves legal protection for the islands and this, together with the development of a Risk Assessment Plan and the intended appointment of an Aliens Officer on the Marion Island over-wintering team, will address the main conservation threat to the islands, namely the introduction of alien species. Dealing with the conservation issues affecting the island group is a full-time task rather than something which can be addressed on an ad hoc basis, and the recent appointment of a full-time Environmental Officer within the Department of Environmental Affairs and Tourism should address this issue. In many aspects, conservation practices at the Prince Edward Islands are as good as or better than those at other subAntarctic island groups (De Villiers et al. 2006a). Notably, and unlike at all the other groups, no fresh produce of any description may be taken to the islands and no tourism (with its attendant problems of increased risks of alien species introductions, trampling, waste management and disturbance of wildlife) is allowed.

However, there is still room for improvement. The islands and their biota are changing rapidly with global climate change. Any decrease in the resilience of species that breed on the islands or forage in the surrounding waters may result in their local extinction. Alien species introductions are a real threat, and many alien species appear to benefit from warmer climatic conditions (Chown et al. 2007). Quarantine procedures around voyages to the island are relatively strict, although they can still be improved. Potential access-routes include insecure storage facilities in Cape Town, inadequately treated materials transported to the islands, and ship-to-shore transport such as helicopters and inflatable dinghies. Despite rigorous quarantine procedures, several alien species have been introduced to Marion Island in recent years. Although the intention to appoint an Aliens Officer on Marion Island is commendable, the effective control or eradication of alien species on the island requires a longterm and properly-funded commitment. The introduced House Mouse on Marion Island is thought to have far-reaching environmental effects, but there has been no intensive monitoring of its population trends for several years. Despite the fact that the eradication of this species will be very expensive, this should be prioritised.

Enforcement of protective legislation onshore is excellent, but is less satisfactory offshore due to the remoteness of the islands from the mainland. Illegal, Unreported and Unregulated fishing remains a problem and has severe consequences in terms of incidental seabird mortalities. Although South Africa now has a fishery patrol vessel which can venture to the islands, the frequency of its trips is currently limited by budgetary constraints. Ongoing 
bilateral negotiations aimed at enhancing international monitoring, control and surveillance co-operation within the Southern Ocean may mitigate this problem. The potential exists for oil and gas exploration, especially offshore, but potentially also onshore. The islands are not protected by legislation in this regard, but the proposed Marine Protected Area will set aside representative marine areas which will not be affected by such activities.

The building of a new research base at the island will render most of the old base buildings defunct. An EIA for the removal of this infrastructure and the rehabilitation of the site has not yet been commissioned. Vast quantities of waste wood will result from the demolition of the old base, and burning of this (rather than its removal for disposal in South Africa) could pose an environmental threat. Thought could be given to alternative, cleaner energy sources than the diesel and petrol generators currently in use at the base and field huts.

A real threat to the seabird colonies on the islands is that of human-mediated disease transmission, e.g. Avian Cholera, Avian Influenza or Newcastle's Disease. Although strict quarantine procedures minimize this risk, these may not be infallible and as yet, no disease contingency plan is in place at the islands.

At the Prince Edward Islands, the effects of climate change on the establishment and spread of alien species, and on the availability of marine resources to the islands' populations of seals and seabirds, cannot be ignored. Long term databases aid in the understanding of environmental change and its effects on ecosystems in general, and populations in particular. For example, the meteorological database at Marion Island goes back to 1949, when the weather station on the island was first established, and data on Wandering Albatrosses have been collected since the establishment of the first study colonies in the 1970s. The delineation of the proposed Marine Protected Area will depend on ongoing monitoring of physical variables such as sea surface temperatures and shifts in the position of frontal systems around the islands, and biological variables such as pelagic phyto- and zooplankton and fish communities and the foraging patterns of the islands' top predators (Lombard et al. 2007). Longterm databases will thus be of inestimable value in the future management and conservation of the islands.

Conservation management attitudes and practices at the Prince Edward Islands have undergone considerable changes in the six decades since annexation. Time will bring new insights, and practices which are currently considered acceptable or even advanced may be subject to criticism in the future. The ideal management strategy will be sensitive to such changes and flexible enough to incorporate the best of these.

\subsection{Acknowledgements}

Henry Valentine (Director: Antarctica and Islands) and past and present members of the Prince Edward Islands Management Committee (PEIMG) 
have invested considerable time and energy in improving the conservation status of the islands. The South African National Antarctic Programme office has also made available minutes of past meetings of the Prince Edward Islands Management Committee as reference material for this chapter. Sarah Davies and Melodie McGeoch are thanked for their helpful comments on an earlier version. Over the years, many scientists have voluntarily taken on the duties of Conservation Officer during annual relief voyages to Marion Island, while various expedition members have, with enthusiasm and dedication, served as Team Conservation Officers during the time that they have made the island their home. To all those people whose passion for the islands has been channelled into their conservation and management, we offer heartfelt thanks.

\subsection{References}

Anderson, D.W. \& Keith, J.O. 1980. The human influence on seabird nesting success: conservation implications. Biological Conservation 18, 65-80.

Angel, A. \& Cooper, J. 2006. A review of the impacts of the introduced rodents of Tristan da Cunha and Gough Island, South Atlantic. Royal Society for the Protection of Birds Research Report No. 17.

Barnes, D.K.A. 2002. Invasions by marine life on plastic debris. Nature $\mathbf{4 1 6}$, 808-809.

Barnes, D.K.A. \& Fraser, K.P.P. 2003. Rafting by five phyla on man-made flotsam in the Southern Ocean. Marine Ecology Progress Series 262, 289-291.

Bester, M.N., Bloomer, J.P., Van Aarde, R.J., Erasmus, B.H., Van Rensburg, P.J.J., Skinner, J.D., et al. 2002. A review of the successful eradication of feral cats from sub-Antarctic Marion Island, southern Indian Ocean. South African fournal of Wildlife Research 32, 65-73.

BirdLife International 2004. Threatened Birds of the World 2004. CD-ROM. BirdLife International, Cambridge.
Black, A. 2005. Light induced seabird mortality on vessels operating in the Southern Ocean: incidents and mitigation measures. Antarctic Science 17, 67-68.

Bloomer, J.P. \& Bester, M.N. 1992. Control of feral cats on sub-Antarctic Marion Island, Indian Ocean. Biological Conservation 60, 211-219.

Born, E.W., Riget, F.F., Dietz, R. \& Andriashek, D. 1999. Escape responses of hauled out Ringed Seals (Phoca hispida) to aircraft disturbance. Polar Biology 21, 171-178.

Boshoff, J.J., Hart, D. \& Loock, J. 1997. Survey of Historical Sites on Marion Island. Unpublished Report for the Prince Edward Islands Management Committee, pp. 1-44.

Boshoff, J.J. \& Van Schalkwyk, J.A. 1999. The Archaeology of Sealing Sites on Marion Island, April/May 1999. Unpublished Report to the South African Heritage Resources Agency.

Brooke, R.K. 1984. South African Red Data Book - Birds. South African National Scientific Programmes Report No. 97. 
Chown, S.L. \& Cooper, J. 1995. The Impact of Feral House Mice at Marion Island and the Desirability of Eradication: Report on a Workshop held at the University of Pretoria, 16-17 February 1995. Directorate: Antarctica \& Islands, Department of Environmental Affairs and Tourism, Pretoria, pp. 1-18.

Chown, S.L., Davies, S.J. \& Joubert, L. 2006. Draft Prince Edward Islands Environmental Management Plan Version 0.1. DST-NRF Centre of Excellence for Invasion Biology, University of Stellenbosch, Stellenbosch, South Africa.

Chown, S.L., Gremmen, N.J.M. \& Gaston, K.J. 1998. Ecological biogeography of Southern Ocean islands: species-area relationships, human impacts, and conservation. American Naturalist 152, 562-575.

Chown, S.L., McGeoch, M.A. \& Marshall, D.J. 2002. Diversity and conservation of invertebrates on the sub-Antarctic Prince Edward Islands. African Entomology 10, 67-82.

Chown, S.L., Slabber, S., McGeoch, M.A., Janion, C. \& Leinaas, H.P. 2007. Phenotypic plasticity mediates climate change responses among invasive and indigenous arthropods. Proceedings of the Royal Society of London $B$ 274, 2531-2537.

Chown, S.L. \& Smith, V.R. 1993. Climate change and the short-term impact of feral house mice at the sub-Antarctic Prince Edward Islands. Oecologia 96, 508-516.

Cooper, J. 1995a. Conservation status of the Prince Edward Islands. In: Dingwall, P.R. (Ed.). Progress in the Conservation of Subantarctic Islands. Proceedings of the SCAR/IUCN Workshop on Protection, Research and Management of Subantarctic Islands, Paimpont, France, 27-29 April, 1992. World Conservation Union, Gland, pp. 21-30.
Cooper, J. 1995b. After the cats and trout: the mice? Removing alien vertebrates from subantarctic Marion Island. Aliens 1, 17.

Cooper, J. 2008. Human history. In: Chown, S.L. \& Froneman, P.W. (Eds.). The Prince Edward Islands. Land-Sea Interactions in a Changing Ecosystem. African Sun Media, Stellenbosch, pp. 331-350.

Cooper, J., Avenant, N.L. \& Lafite, P.W. 1994a. Airdrops and King Penguins: a potential conservation problem at sub-Antarctic Marion Island. Polar Record 30, 277-282.

Cooper, J. \& Avery, G. (Eds.). 1986. Historical Sites at the Prince Edward Islands. South African National Scientific Programmes Report 128, CSIR, Pretoria.

Cooper, J., Brooke, M.de L., Burger, A.E., Crawford, R.J.M., Hunter, S. \& Williams, A.J. 2001. Aspects of the breeding biology of the Northern Giant Petrel (Macronectes halli) and the Southern Giant Petrel (M. giganteus) at sub-Antarctic Marion Island. International Fournal of Ornithology $\mathbf{4}$, 53-68.

Cooper, J. \& Condy, P.R. 1988. Environmental conservation at the sub-Antarctic Prince Edward Islands: a review and recommendations. Environmental Conservation 15, 317-326.

Cooper, J., Crafford, J.E. \& Hecht, T. 1992. Introduction and extinction of Brown Trout (Salmo trutta L.) in an impoverished sub-Antarctic stream. Antarctic Science 4, 9-14.

Cooper, J., de Villiers, M.S. \& McGeoch, M.A. 2003. Quarantine measures to halt alien invasions of Southern Ocean Islands: the South African experience (Prince Edward Islands Special Nature Reserve). Aliens 17, 37-39. 
Cooper, J. \& Fourie, A. 1991. Improved breeding success of Great-winged Petrels Pterodroma macroptera following control of feral cats Felis catus at subantarctic Marion Island. Bird Conservation International 1, 171-175.

Cooper, J. \& Headland, R.K. 1991. A history of South African involvement in Antarctica and at the Prince Edward Islands. South African Fournal of Antarctic Research 21, 77-91.

Cooper, J., Marais, A.v.N., Bloomer, J.P. \& Bester, M.N. 1995. A success story: breeding of burrowing petrels (Procellariidae) before and after eradication of feral cats Felis catus at subantarctic Marion Island. Marine Ornithology 23, 33-37.

Cooper, J. \& Ryan, P.G. 2001. The Agreement on the Conservation of Albatrosses and Petrels: implications for research and monitoring at the Prince Edward Islands. South African Fournal of Science 97, 78-79.

Cooper, J. \& Ryan. P.G. 2003. South African National Plan of Action for Reducing the Incidental Catch of Seabirds in Longline Fisheries. Unpublished Report to the Branch: Marine and Coastal Management, Department of Environmental Affairs \& Tourism, pp. 1-103.

Cooper, J., Van Wyk, J.C.P. \& Matthewson, D.C. 1994b. Effects of small-mammal trapping on birds at sub-Antarctic Marion Island. South African Fournal of Antarctic Research 24, 125.

Crafford, J.E. \& Chown, S.L. 1987. Plutella xylostella (Lepidoptera: Plutellidae) on Marion Island. Fournal of the Entomological Society of Southern Africa 50, 259-260.
Crafford, J.E. \& Chown, S.L. 1990. The introduction and establishment of the Diamondbacked Moth (Plutella xylostella L., Plutellidae) on Marion Island. In: Kerry, K.R. \& Hempel, G. (Eds.). Antarctic Ecosystems. Ecological Change and Conservation. Springer, Berlin, pp. 354-358.

Crafford, J.E. \& Scholtz, C.H. 1987. Quantitative differences between the insect faunas of sub-Antarctic Marion and Prince Edward Islands: a result of human intervention? Biological Conservation 40, 255-262.

Crawford, A.B. 1952. The birds of Marion Island, Southern Indian Ocean. Ети 52, 73-85.

Crawford, R.J.M., Cooper, J., du Toit, M., Greyling, M.D., Hanise, B., Holness, G.L., et al. 2003a. Population and breeding of the Gentoo Penguin Pygoscelis papua at Marion Island, 1994/95-2002/03. African fournal of Marine Science 25, 463-474.

Crawford, R.J.M., Cooper, J., Dyer, B.M., Wolfaardt, A.C., Tshingana, D., Spencer, K., et al. 2003b. Population, breeding, diet and conservation of the Crozet Shag Phalacrocorax [atriceps] melanogenis at Marion Island, 1994/95-2002/03. African fournal of Marine Science 25, 537-547.

Crawford, R.J.M., Duncombe Rae, C.M., Nel, D.C. \& Cooper, J. 2003c. Unusual breeding by seabirds at Marion Island during 1997/98. African Journal of Marine Science 25, 453-462.

Crawford, R.J.M., Duncombe Rae, C.M., Nel, D.C. \& Cooper, J. 2004. Influence of climate on seabirds at sub-Antarctic Marion Island, Southern Ocean. 27th Antarctic Treaty Consultative Meeting Information Paper IP 076. 
Crawford, R.J.M., Dyer, B.M., de Villiers, M.S., Hofmeyr, G.J.G. \& Tshingana, D. 2005. Mortality of Macaroni Penguins Eudyptes chrysolophus at Marion Island caused by Avian Cholera Pasteurella multocida in 2004/05. CCAMLR WG-EMM-05/.

De Villiers, M.S., Bause, M., Giese, M. \& Fourie, A. 2006b. Hardly hard-hearted: heart rate responses of incubating Northern Giant Petrels (Macronectes halli) to human disturbance on sub-Antarctic Marion Island. Polar Biology 29, 717-720.

De Villiers, M.S., Cooper, J., Carmichael, N., Glass, J.P., Liddle, G.M., McIvor, E., et al. 2006a. Conservation management at Southern Ocean Islands: towards the development of best-practice guidelines. Polarforschung 75, 113-131.

De Villiers, M.S., Cooper, J. \& Ryan, P.G. 2005. Individual variability of behavioural responses by Wandering Albatrosses (Diomedea exulans) to human disturbance. Polar Biology 28, 255-260.

Environomics 2002. Report on the Scoping Study for the Proposed New Base Facility at Marion Island. Environomics, Pretoria.

Frenot, Y., Chown, S.L., Whinam, J., Selkirk, P.M., Convey, P., Skotnicki, M., et al. 2005. Biological invasions in the Antarctic: extent, impacts and implications. Biological Reviews $\mathbf{8 0}$, 45-72.

Gales, R. 1998. Albatross populations: status and threats. In: Robertson, G. \& Gales, R. (Eds.). Albatross Biology and Conservation. Surrey Beatty, Chipping Norton, pp. 20-45.
Gardner, B.D., Siegfried, W.R. \& Connell, A.D. 1985. Chlorinated hydrocarbons in seabird eggs from the southern Atlantic and Indian Oceans. In: Siegfried, W.R. Condy, P.R. \& Laws, R.M. (Eds.). Antarctic Nutrient Cycles and Food Webs. SpringerVerlag, Berlin, pp. 647-651.

Giese, M. 1996. Effects of human activity on Adélie Penguin Pygoscelis adeliae breeding success. Biological Conservation 75, 157-164.

Giese, M. 1998. Guidelines for people approaching breeding groups of Adélie Penguins (Psygoscelis adeliae). Polar Record 34, 287-292.

Graham, T. 1989. Cultural Resource Management of the Prince Edward Islands. B.A. (Hons) Dissertation, University of Cape Town, South Africa.

Gremmen, N.J.M. 1975. The distribution of alien vascular plants on Marion and Prince Edward Islands. South African Fournal of Antarctic Research 5, 25-30.

Gremmen, N.J.M. 2004. Management of Alien Vascular Plants on Marion and Prince Edward Islands: an Integrated Approach. Data Analyse Ecologie, The Netherlands.

Gremmen, N.J.M., Chown, S.L. \& Marshall, D.J. 1998. Impact of the introduced grass Agrostis stolonifera on vegetation and soil fauna communities at Marion Island, sub-Antarctic. Biological Conservation 85, 223-231.

Gremmen, N.J.M. \& Smith, V.R. 1999. New records of alien vascular plants from Marion and Prince Edward Islands, sub-Antarctic. Polar Biology 21, 401-409. 
Gremmen, N.J.M., Smith, V.R. \& Van Tongeren, O.F.R. 2003. Impact of trampling on the vegetation of Subantarctic Marion Island. Arctic, Antarctic, and Alpine Research 35, 442-446.

Gremmen, N.J.M. \& Van der Meijden, R. 1995. Introduced Agrostis species at sub-Antarctic Marion Island. South African Journal of Antarctic Research 25, 85-86.

Grindley, J.R. 1981. Observations of seabirds at Marion and Prince Edward Islands in April and May 1973. In: Cooper, J. (Ed.). Proceedings of the Symposium on Birds of the Sea and Shore, 1979. African Seabird Group, Cape Town, pp 169-188.

Hänel, C. \& Chown, S.L. 1998. An Introductory Guide to the Marion and Prince Edward Island Special Nature Reserves 50 Years after Annexation. Department of Environmental Affairs and Tourism, Pretoria, pp. 1-80.

Hänel, C., Chown, S.L. \& Davies, L. 1998. Records of alien insect species from sub-Antarctic Marion and South Georgia Islands. African Entomology 6, 366-369.

Heydenrych, R. \& Jackson, S. 2000. Environmental Impact Assessment of Tourism on Marion Island. Department of Environmental Affairs and Tourism, Pretoria, pp. 1-115.

Heymann, G., Erasmus, T., Huntley, B.J., Liebenberg, A.C., Retief, G. de F., Condy, P.R., et al. 1987. An environmental impact assessment of a proposed emergency landing facility on Marion Island - 1987. South African National Scientific Programmes Report No.140.

Hofmeyr, G., De Maine, M., Bester, M., Kirkman, S., Pistorius, P. \& Makhado, A. 2002. Entanglement of pinnipeds at Marion Island, Southern Ocean: 1991-2001. Australian Mammalogy 24, 141-146.
Hugo, E.A., Chown, S.L. \& McGeoch, M.A. 2006. The microarthropods of Prince Edward Island: A quantitative assessment. Polar Biology 30, 109-1 19.

Huyser, O., Ryan, P.G. \& Cooper, J. 2000. Changes in population size, habitat use and breeding biology of Lesser Sheathbills Chionis minor at Marion Island: impacts of cats, mice and climate change? Biological Conservation 92, 299-310.

Jackson, S. and Wilson, R.P. 2002. The potential costs of flipper-bands to penguins. Functional Ecology 16, 141-148.

Jansen Van Vuuren, B. \& Chown, S.L. 2007. Genetic evidence confirms the origin of the House Mouse on subAntarctic Marion Island. Polar Biology 30, 327-332.

Kloppers, FJ. \& Smith, V.R. 1998. First report of Botryotinia fuckeliana on Kerguelen Cabbage on the sub-Antarctic Marion Island. Plant Disease 82, 710.

Knops, J.M.H., Bradley, K.L. \& Wedin, D.A. 2002. Mechanisms of species impacts on ecosystem nitrogen cycling. Ecology Letters 5, 454-466.

La Grange, J.J. 1962. Notes on the birds and mammals on Marion Island and Antarctica (S.A.N.A.E.). Fournal of the South African Biological Society 3, 27-84.

Lee, J.E. \& Chown, S.L. 2007. Mytilus on the move: transport of an invasive bivalve to the Antarctic. Marine Ecology Progress Series 339, 307-310.

Lee, J.E. Slabber, S., Jansen Van Vuuren, B., Van Noort, S. \& Chown, S.L. 2007. Colonisation of sub-Antarctic Marion Island by a non-indigenous aphid parasitoid Aphidius matricariae (Hymenoptera, Braconidae). Polar Biology 30, 1195-1201. 
Lewis, P.N., Hewitt, G.L., Riddle, M. \& McMinn, A. 2003. Marine introductions in the Southern Ocean: an unrecognized hazard to biodiversity. Marine Pollution Bulletin 46, 213-223.

Lombard, A.T., Reyers, B., Schonegevel, L., Cooper, J., Smith-Adao, L., Nel, D.C., et al. 2007. Conserving pattern and process in the Southern Ocean: designing a Marine Protected Area for the Prince Edward Islands. Antarctic Science 19, 39-54.

Mélice, J-L., Lutjeharms, J.R.E., Rouault, M. \& Ansorge, I.J. 2003. Sea-surface temperatures at the subAntarctic islands Marion and Gough during the past 50 years. South African Journal of Science 99, 363-366.

Nel, D.C. \& Nel, J.L. 1999. Marine debris and fishing gear associated with seabirds at sub-Antarctic Marion Island, 1996/97 and 1997/98: in relation to longline fishing activity. CCAMLR Science $\mathbf{6}$, 85-96.

Nel, D.C., Nel, J.C., Ryan, P.G., Klages, N.T.W., Wilson, R.P. \& Robertson, G. 2000. Foraging ecology of Greyheaded Mollymawks at Marion Island, southern Indian Ocean, in relation to longline fishing activity. Biological Conservation 96, 219-231.

Nel, D.G., Ryan, P.G., Crawford, R.J.M., Cooper, J. \& Huyser, O.A.W. 2002a. Population trends of albatrosses and petrels at sub-Antarctic Marion Island. Polar Biology 25, 81-89.

Nel, D.C., Ryan, P.G., Nel, J.L., Klages, N.T.W., Wilson, R.P., Robertson, G., et al. 2002b. Foraging interactions of Wandering Albatrosses Diomedea exulans breeding on Marion Island with long-line fisheries in the southern Indian Ocean. Ibis 144, 141-154.
Nel, D.C., Ryan, P.G. \& Watkins, B.P. 2002c. Seabird mortality in the Patagonian Toothfish fishery around the Prince Edward islands, 19962000. Antarctic Science 14, 151-161.

Nel, D.C. \& Whittington, P.A. 2003. Rehabilitation of Oiled African Penguins: a Conservation Success Story. BirdLife South Africa and the Avian Demography Unit, Cape Town.

Pakhomov, E.A. \& Chown, S.L. 2003. The Prince Edward Islands: Southern Ocean oasis. Ocean Yearbook 17, 348-379.

PEIMPWG (Prince Edward Islands Management Plan Working Group) 1996. Prince Edward Islands Management Plan. Department of Environmental Affairs \& Tourism, Pretoria, pp. 1-64.

Petersen, S.L., Branch, G.M., Ainley, D.G., Boersma, P.D., Cooper, J. \& Woehler, E.J. 2005. Is flipper banding of penguins a problem? Marine Ornithology 33, 75-79.

Roth, L.M. \& Willis, E.R. 1960. The biotic associations of cockroaches. Smithsonian Institute Miscellaneous Collection 141, 1-470.

Rounsevell, D. \& Binns, D. 1991. Mass deaths of King Penguins (Aptenodytes patagonica) at Lusitania Bay, Macquarie Island. Aurora 10, 8-10.

Ryan, P.G. 1987. The origin and fate of artefacts stranded on islands in the African sector of the Southern Ocean. Environmental Conservation, 14, 341-346.

Ryan, P.G. 1990. The marine plastic debris problem off southern Africa: Types of debris, their environmental effects, and control measures. In: Shomura, R.S. \& Godfrey, M.L. (Eds.). Proceedings of the Second International Conference on Marine Debris, 2-7 April 1898. Honolulu, Hawaii. 
Ryan, P.G. 1996. Plastic litter in marine systems: Impacts, sources and solutions. Plastics Southern Africa. November 1996, 20-28.

Ryan, P.G. \& Moloney, G.L. 1993. Marine litter keeps increasing. Nature 361, 23.

Ryan, P.G., Smith, V.R. \& Gremmen, N.J.M. 2003. The distribution and spread of alien vascular plants on Prince Edward Island. African fournal of Marine Science 25, 555-561.

Slabber, S. \& Chown, S.L. 2002. The first record of a terrestrial crustacean, Porcellio scaber (Isopoda, Porcellionidae) from sub-Antarctic Marion Island. Polar Biology 25, 855-858.

Smith, V.R. 2002. Climate change in the sub-Antarctic: an illustration from Marion Island. Climate Change 52, 345-357.

Smith, V.R. \& Steenkamp, M. 1990. Climatic change and its ecological implications at a subantarctic island. Oecologia 85, 14-24.

South Africa. 2005. Towards the creation of a Marine Protected Area around South Africa's sub-Antarctic Prince Edward Islands. 28th Antarctic Treaty Consultative Meeting, IP 019.

Van Aarde, R.J. 1979. Distribution and density of the feral house cat Felis catus on Marion Island. South African Fournal of Antarctic Research 9, 14-19.

Van Zinderen Bakker, E.M. Jr. 1971. The genus Diomedea. In: Van Zinderen Bakker, E.M., Winterbottom, J.M. \& Dyer, R.A. (Eds.). Marion and Prince Edward Islands. Report on the South African Biological and Geological Expedition 1965-1966. Balkema, Cape Town. pp. 273-282.
Visagie, W.F. 1988. Code of Conduct for the Prince Edward Islands. Department of Environment Affairs, Pretoria.

Vleck, C.M., Vertalino, N., Vleck, D. \& Bucher, T.L. 2000. Stress, corticosterone, and heterophil to lymphocyte ratios in free-living Adélie penguins. The Condor 102, 392-400.

Watkins, B.P. 1987. Population sizes of King, Rockhopper and Macaroni Penguins and Wandering Albatrosses at the Prince Edward Islands and Gough Island, 1951-1986. South African Journal of Antarctic Research 17, 150-157.

Watkins, B.P. \& Cooper, J. 1986. Introduction, present status and control of alien species at the Prince Edward islands, sub-Antarctic. South African Fournal of Antarctic Research 16, 86-94.

Whinam, J., Chilcott, N. \& Bergstrom, D.M. 2005. Subantarctic hitchhikers: expeditioners as vectors for the introduction of alien organisms. Biological Conservation 121, 207-219.

Williams, A.J. 1984. The status and conservation of seabirds on some islands in the African sector of the Southern Ocean. International Council for Bird Preservation Technical Publication 2, 627-635.

Woehler, E.J., Penney, R.L., Creet, S.M. \& Burton, H.R. 1994. Impacts of human visitors on breeding success and long-term population trends in Adélie Penguins at Casey, Antarctica. Polar Biology 14, 269-274. 